\title{
Omics analysis reveals variations among commercial sources of bovine milk fat globule membrane
}

\author{
Lauren R. Brink, ${ }^{1} \odot$ Anthony W. Herren, ${ }^{2}$ Shasta McMillen, ${ }^{1} \odot$ Karl Fraser, ${ }^{3,4,5} \oplus$ Michael Agnew, ${ }^{6} \odot$ \\ Nicole Roy, ${ }^{3,4,6}$ a and Bo Lönnerdal ${ }^{1 *}$ \\ ${ }^{1}$ Department of Nutrition, University of California, Davis 95616 \\ ${ }^{2}$ Genome Center, University of California, Davis 95616 \\ ${ }^{3}$ Food Nutrition and Health Team, AgResearch, Grasslands Research Centre, Palmerston North 4442, New Zealand \\ ${ }^{4}$ Riddet Institute, Massey University, Palmerston North 4474, New Zealand \\ ${ }^{5}$ High-Value Nutrition National Science Challenge, Auckland 1023, New Zealand \\ ${ }^{6}$ Dairy Foods Team, AgResearch, Grasslands Research Centre, Palmerston North 4442, New Zealand
}

\begin{abstract}
Milk fat globule membrane (MFGM) is a glycosylated, protein-embedded, phospholipid fraction that surrounds triglycerides in milk. Commercial bovine sources have recently come to the market as a novel food ingredient and have been added to various products, including infant formula. Considering that MFGM is a heterogeneous mixture of fat, protein, and carbohydrate, it can be expected that variations among MFGM products exist. For this reason, our aim was to characterize the composition of commercial MFGM samples through a combination of proteomic and lipidomic analyses. Six bovine milk fractions, represented as MFGM fractions or phospholipid fractions, were obtained from various commercial sources. Additionally, the MFGM samples were compared with 2 infant formulas, a standard formula as well as a premium formula containing MFGM. For proteomic analysis, bottom-up data-dependent liquid chromatography-tandem mass spectrometry (LCMS/MS) was performed on each MFGM fraction, and nearly a thousand proteins were identified across all samples, with 364 of them having different abundance across the samples tested. One hundred twelve proteins differed by a fold-change of 10 or greater, 14 by a foldchange of 50, and 2 by a fold-change of 100 in at least 1 pair, suggesting large differences in the proteins present in these fractions. Even though the classical MFGM proteins were enriched in the MFGM fractions, the relative protein composition varied considerably, and all contain an abundance of milk (casein and whey) proteins. Lipidomic analysis identified a total of 393
\end{abstract}

Received June 27, 2019.

Accepted December 1, 2019.

*Corresponding author: bllonnerdal@ucdavis.edu lipid species across both positive and negative ionization modes, with the major classes detected being triglycerides, sphingomyelins, and several phospholipids. Across all samples, triglycerides comprised at least $50 \%$ of total lipids, with phosphatidylcholine and sphingomyelin being the second and third most abundant lipid classes, respectively. These findings demonstrate the heterogeneous nature of various bovine commercial MFGM fractions. This variation must be considered when evaluating and describing potential functional benefits of these products shown in clinical trials.

Key words: milk fat globule membrane (MFGM), beta serum concentrate (BSC), phospholipid, sialic acid, commercial product

\section{INTRODUCTION}

Milk fat globule membrane (MFGM) is the lipid delivery vehicle of milk. A cytosolic lipid droplet originating from the endoplasmic reticulum carries triglycerides (TG) to the plasma membrane of secreting cells, at which point it is enveloped and excreted with the plasma membrane layer. Thus, MFGM is a tri-phospholipid membrane layer, containing a variety of lipids and proteins (glycosylated and associated with the membrane layer) and carbohydrate moieties (Dewettinck et al., 2008; Martini et al., 2016). Recently interest has increased in MFGM- and phospholipid (PL)-enriched products as potential value-added ingredients, and their use as a nutraceutical has been reviewed previously (Spitsberg, 2005). Commercial sources of MFGM are whey or cream derived, and different sources will affect its composition. Some food products naturally contain high amounts of MFGM, such as buttermilk. In the marketplace, MFGM-like products have also been described as beta serum or PL concentrates.

A heterogeneous milk fraction, the components of MFGM have been implicated in various health benefits. 
For example, the proteins, polar lipid metabolites, and gangliosides in MFGM have been studied in vitro for their anti-adhesive (Otnaess et al., 1983; Stevens et al., 2000; Kvistgaard et al., 2004; Martín et al., 2004; Bu et al., 2007; Liu et al., 2012; Fuller et al., 2013; Novakovic et al., 2015) and antibacterial properties (Idota et al., 1995; Hester et al., 2013). The polar lipids and sialic acid-containing components [glycosylated proteins and sphingomyelin (SM)] have been studied for biologic activities involved in improved neurodevelopment (Oshida et al., 2003; McJarrow et al., 2009; Tanaka et al., 2013; Palmano et al., 2015; Mudd et al., 2016; Schipper et al., 2016; Brink and Lönnerdal, 2018; Moukarzel et al., 2018; Brink et al., 2019). There is considerable interest in adding MFGM to infant nutrition products. Indeed, clinical trials investigating their addition to infant formula and complementary foods have been performed, with the primary outcomes related to neurologic (Gurnida et al., 2012; Veereman-Wauters et al., 2012; Timby et al., 2014) and immune development (Zavaleta et al., 2011; Billeaud et al., 2014; Poppitt et al., 2014; Timby et al., 2015). The clinical evidence regarding the benefits of adding MFGM to products for infants and children has recently been reviewed (Hernell et al., 2016). Additionally, MFGM has been investigated in adults with regard to safety and tolerability (Hari et al., 2015), parameters of frailty and physical function (Kim et al., 2015; Soga et al., 2015; Minegishi et al., 2016), cardiovascular disease biomarkers (Rosqvist et al., 2015), bone turnover and inflammation (Rogers et al., 2017), skin conditions (Higurashi et al., 2015), and infection by Escherichia coli (Ten Bruggencate et al., 2016).

These clinical investigations suggest that MFGM may be a promising functional food additive for individuals across the lifespan. However, when evaluating these trials and the health-related bioactivities of MFGM, it becomes important to assess its composition. As a complex fraction, the biologic activities of MFGM may be influenced by the relative proportions of its constituent components. Further, MFGM is available commercially from several companies, and the degree to which its composition varies by source is unknown. Considering that MFGM products are based on various raw materials and produced using different processing techniques, it is important to investigate the similarities and differences among products. The size of fat globules could be another source of variation, as protein and lipid composition of MFGM varies with droplet size (Lu et al., 2016a). Using a variety of methods, our aim was to describe the composition of MFGM products from multiple suppliers to assess the variability in available MFGM products.

\section{MATERIALS AND METHODS}

\section{Sample Procurement}

Table 1 describes the products examined, their company of origin, their ingredient origin (incorporated, whey, or cream-based), and their designation within this report. Two infant formulas were also investigated, to demonstrate their variation from the MFGM samples. Both formulas were purchased in the United States from the Enfamil brand (Mead Johnson Nutrition, Evansville, IN). Their standard infant formula (referred to as $\mathbf{S F}$ in this study) as well as their Enspire Formula (which contains MFGM and lactoferrin and is referred to as $\mathbf{P F}$ in this study) were examined. The MFGM products were provided upon request from the producers. Lacprodan MFGM-10 (MFGM-10), a whey-derived ingredient, and Lacprodan PL-20 (PL20), a cream-derived ingredient, were provided by Arla Food Ingredients (Viby J, Denmark). Beta serum concentrate (BPC-50), a cream-derived ingredient, was acquired from Fonterra (Auckland, New Zealand). The sample provided was a portion of the material used for a clinical study performed at the USDA Western Regional Research Center (Davis, CA; Rogers et al., 2017). Tatua (Tatuanui, New Zealand) provided 2 cream-derived ingredients, PL concentrate (PLC1) and beta serum concentrate (BSP2), and the Corman product (Limbourg, Belgium) was a sweet buttermilk powder (SM2). All samples were bovine (Bos taurus)sourced and were stored at $4^{\circ} \mathrm{C}$ until processing. The purpose of this study was to emphasize the variability among the various commercial sources. However, only 1 sample from each manufacturer was subjected to the analyses performed. Batch-to-batch variations likely also exist for each commercial product, but this was not studied. Further, variations could occur due to cow stage of lactation. However, these were commercially sourced ingredients, originating from pooled dairy sources at very large dairy companies. Thus, we are unsure of the different lactation stages of the cows from which samples were collected.

\section{Lipidomics}

Samples were solubilized in water (Milli-Q; Millipore, Burlington, MA) by vigorous shaking (60 s) and left overnight at $4^{\circ} \mathrm{C}$ to achieve a concentration of $12.5 \%$ (wt/vol). A 300- $\mu \mathrm{L}$ aliquot of each sample solution was then extracted with $1 \mathrm{~mL}$ of chloroform:methanol $(2: 1 \mathrm{vol} / \mathrm{vol})$ containing $10 \mu \mathrm{g} / \mathrm{mL}$ of internal standard (16:0 d31-18:1 phosphatidylethanolamine) and shaken (1 min). Next, $300 \mu \mathrm{L}$ of water was added, vortex mixed 


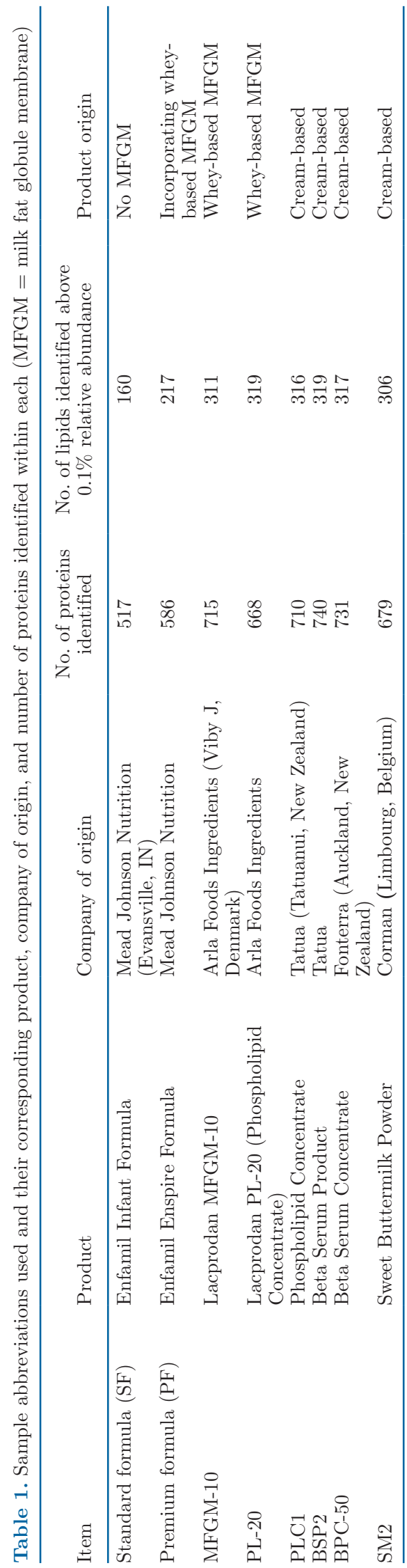

for $30 \mathrm{~s}$, and then centrifuged for $10 \mathrm{~min}$ at $13,000 \times$ $g$ at $4^{\circ} \mathrm{C}$, and $100 \mu \mathrm{L}$ of the lower phase (organic) was transferred to a glass insert in a sample vial for lipid analysis. Aliquots of each of the 8 extracts were pooled to create a pooled quality control sample, for monitoring instrument performance and reproducibility.

Ultra-Performance Liquid Chromatography/ High-Resolution Mass Spectrometry Analysis. Mass spectrometric analysis was carried out on a Q-Exactive Mass Spectrometer (Thermo Fisher Scientific, Waltham, MA), using positive and negative electrospray ionization, and the data collected from $m / z$ 200-2,000 for the $\mathrm{MS}^{1}$ spectra. Because MFGM is known to contain lipids of many glycerolipid and PL classes, and not all lipid classes ionize optimally (or at all, in some cases) in a single ionization mode, samples were analyzed in both positive and negative modes separately, to ensure that maximal coverage of the MFGM lipidome was achieved. The mass spectrometer was programmed to collect data-dependent $\mathrm{MS}^{2}$ fragmentation spectra on the most abundant ions in the $\mathrm{MS}^{1}$ scan with a normalized collision energy setting of 30. The capillary temperature was $300^{\circ} \mathrm{C}$ and the source voltage set to $4.0 \mathrm{kV}$ for both ionization modes. The chromatographic system consisted of an Accela 1250 pump (Thermo Fisher Scientific) and a CTC PAL autosampler. Samples were injected $(2 \mu \mathrm{L})$ onto an Acquity CSH C18 column $(1.7 \mu \mathrm{m}, 2.1 \mathrm{~mm} \times 100 \mathrm{~mm}$; Waters Corp., Milford, MA). Lipids were eluted over a 15 -min gradient from $85 \%$ solvent A $60 \%$ acetonitrile, $0.1 \%$ formic acid, $10 \mathrm{mM} \mathrm{NH} \mathrm{NH}_{4} \mathrm{COOH}$ in Milli-Q water) to $99 \%$ solvent B (90\% isopropanol, $10 \%$ acetonitrile, $0.1 \%$ formic acid, $10 \mathrm{mM} \mathrm{NH} \mathrm{NHOH}_{4} \mathrm{COO}$. The $\mathrm{MS}^{1}$ mass spectral data for quantifying the peak areas via XCMS (Smith et al., 2006) was collected at 70,000 resolution, and the data-dependent $\mathrm{MS}^{2}$ spectral data used for identification with LipidSearch software (Thermo Fisher Scientific) was collected at 35,000 resolution.

Data Analysis. Peak areas were extracted from the samples using the non-targeted peak detection tool XCMS (Smith et al., 2006). The resultant data matrix was matched with the lipid ions identified by the LipidSearch, to annotate the lipid species using $\mathrm{MS}^{2}$ spectral data. Pooled quality control samples were measured before and after the MFGM samples, to monitor instrument performance and reproducibility. Data analysis was performed in $\mathrm{R}$ (version 3.4.1) using R Studio (version 1.0.153; R Foundation for Statistical Computing, Vienna, Austria). Data were transformed with the $\log$ value +1 . Principal component analysis (PCA) was performed with the prcomp package, and the calculation was based on a singular-value decomposition. Hierarchical clustering was performed with the hclust function in the stat package and plotted with the 
ggdendro package. Ggplot2, ggrepel, and dplyr packages were also used for the data visualization.

\section{Proteomics}

Sample Preparation. For proteomic analysis, samples were batch processed in technical triplicate, whereby $10 \mathrm{mg}$ of each MFGM or infant formula dry powder was extracted in $1 \mathrm{~mL}$ of solubilization buffer (5\% SDS, $50 \mathrm{~m} M$ tetraethylammonium bromide (TEAB), $1 \times$ PhosSTOP phosphatase, and $1 \times$ Complete Mini Protease Inhibitor tablets (Roche, Basel, Switzerland), along with probe sonication. Samples were clarified by centrifugation at $15,000 \times g$ for 10 min and the resulting supernatant taken for analysis. For each sample, protein concentration was determined by bicinchoninic acid (BCA) assay (Pierce Protein Biology, Thermo Fisher Scientific), volume was normalized to $150 \mathrm{ug}$ of total protein, reduced and alkylated, and enzymatically digested with trypsin using S-Trap mini spin columns according to manufacturer instructions (Protifi, Farmingdale, NY), with the following modifications: samples were reduced with $20 \mathrm{mM}$ dithiothreitol (Sigma-Aldrich, St. Louis, MO) for $10 \mathrm{~min}$ at $95^{\circ} \mathrm{C}$, alkylated with $40 \mathrm{~m} M$ iodoacetamide (SigmaAldrich) for $30 \mathrm{~min}$ at room temperature, and trypsin (Worthington Biochemical Corp., Lakewood, NJ) was added at a 1:12.5 ratio [enzyme $(\mu \mathrm{g})$ :protein $(\mu \mathrm{g})$ ] and reacted for $2 \mathrm{~h}$ at $47^{\circ} \mathrm{C}$. Samples were dried in a CentriVap centrifugal vacuum concentrator (Labconco, Kansas City, MO) and reconstituted in $2 \%$ acetonitrile, $0.1 \%$ TFA for liquid chromatography-tandem mass spectrometry (LC-MS/MS) analysis.

$L C-M S / M S$. Digested peptides were analyzed by LC-MS/MS on a Thermo Fisher Scientific Q Exactive Plus Orbitrap Mass Spectrometer in conjunction with an EASY-nLC 1200 UHPLC and Proxeon nanospray source operating in positive ionization mode. Peptides were loaded on a $100 \mu \mathrm{m} \times 25 \mathrm{~mm}$ Magic C18 $100 \AA$ $5 \mathrm{U}$ reverse-phase trap before being separated using a

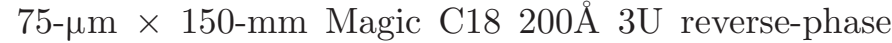
column. Peptides were eluted with an increasing percentage of acetonitrile over the course of a 180-min gradient with a flow rate of $300 \mathrm{~nL} / \mathrm{min}$. An MS survey scan was obtained for the $\mathrm{m} / z$ range 350 to 1,600 and acquired with a resolution of 70,000 and a target of 1 $\times 10^{6}$ ions or a maximum injection time of 30 msec. The $\mathrm{MS}^{2}$ spectra were acquired using a top-15 method, where the top 15 ions in the MS spectra were subjected to high-energy collisional dissociation (HCD). The $\mathrm{MS}^{2}$ spectra were acquired with a resolution of 17,500 and a target of $5 \times 10^{4}$ ions or a maximum injection time of $50 \mathrm{msec}$. An isolation mass window of $1.6 \mathrm{~m} / z$ was used for precursor ion selection, charge states 2 to 4 were accepted, and a normalized collision energy of 27 was used for fragmentation. A 20-s duration was used for dynamic exclusion.

Data Analysis. Raw DDA files were searched with Andromeda in MaxQuant (version 1.6.1.0; https: //www.maxquant.org/) using default Orbitrap settings. Briefly, a target-decoy search strategy was utilized against a Bos taurus protein sequence database (downloaded February 15, 2018, from uniprot.org), consisting of 23,968 protein sequences amended with 97 potential contaminants from the cRAP database of common laboratory contaminants (www.thegpm.org/ crap) and an equal number of reverse decoys. Identifications were made at $1 \%$ protein and peptide FDR with match between runs and second peptides enabled. Searches were configured for trypsin, allowing for 2 missed cleavages, and carbamidomethylation of Cys as a fixed modification. Up to 5 variable modifications were allowed per peptide, including oxidation of Met; N-terminal acetylation; Gln to pyro-Glu and Glu to pyro-Glu; phosphorylation of Ser, Thr, and Tyr; and deamidation of Asn and Gln. Instrument parameters and match tolerances were set to Orbitrap defaults. Label-free quantitation was performed with the fast MaxLFQ algorithm and intensity-based absolute quantification (IBAQ), using unique and razor peptides (not containing variable modifications) with a requirement for 2 shared peptides, and large LFQ ratio stabilization enabled.

MaxQuant data output was loaded into Perseus version 1.6.0.2 (https://www.maxquant.org/perseus/) for further processing and statistics. Proteins designated as reverse, contaminant, or only identified through a post-translational modification site, were removed from further processing. For identification, proteins required identification by at least 1 non-redundant peptide (unique or razor) with $\mathrm{MS}^{2}$ identification or matching. For quantitation, normalized LFQ or IBAQ protein intensities were used, allowing for matching. To be considered valid, a protein required nonzero intensity values for all 3 technical replicates from at least 1 product group. Intensity values were log base 2 transformed and remaining missing values imputed. For differential protein abundance across groups, an ANOVA test was performed with Benjamini-Hochberg (BH) FDR multiple testing correction, using a significance threshold of 0.05 .

To determine identity of uncharacterized proteins, sequences were searched with the Basic Local Alignment Search Tool (BLAST; https://blast.ncbi.nlm.nih .gov/Blast.cgi). The bovine identity was first considered, followed by the human equivalent. Homology had to be greater than $60 \%$ to be classified. Proteins are displayed by their corresponding UniProt names. 


\section{Immunoblotting}

Dry MFGM samples were rehydrated in MilliQ at a concentration of $2 \% \mathrm{wt} / \mathrm{vol}$ and loaded onto $10 \%$ TGX FastCast polyacrylamide gels (Bio-Rad, Hercules, CA). Specifically, $200 \mathrm{mg}$ of each MFGM or formula sample were dissolved in $10 \mathrm{~mL}$ of pure water, then aliquoted into $1-\mathrm{mL}$ samples. Protein was loaded at $20 \mu \mathrm{g}$ per well. After $85 \mathrm{~min}$ of electrophoresis under reducing conditions at $125 \mathrm{~V}$, proteins were transferred to nitrocellulose membrane and blocked with SEA BLOCK (Thermo Fisher Scientific) for $60 \mathrm{~min}$ at room temp. Membranes were washed and incubated in primary antibody (rabbit anti-xanthine oxidase, 1:500, Abcam, Cambridge, MA) at $4^{\circ} \mathrm{C}$ overnight. Blots were then washed, incubated in horseradish peroxidase-conjugated secondary antibody, treated with HyGLOQuick Spray reagent (Denville Scientific, Holliston, MA), and detected using a ChemiDoc MP Imaging System (Bio-Rad). Total protein per lane was assessed using the stain-free method, and band density was analyzed relative to total protein using ImageLab software (Bio$\mathrm{Rad})$. Western blots were repeated $(\mathrm{n}=3)$ to serve as technical replicates.

\section{Sialic Acid Assay}

Sialic acid was determined based on methods published previously (Martín et al., 2007). Briefly, the sample was reconstituted in water (0.75-g sample to a total of $10 \mathrm{~g}$ with water), mixed by placing in water bath at $50^{\circ} \mathrm{C}$ for $2 \mathrm{~h}$, with mixing by inversion every $30 \mathrm{~min}$. An aliquot was hydrolyzed with $0.05 \mathrm{M} \mathrm{H}_{2} \mathrm{SO}_{4}$ $\left(1.5 \mathrm{~h}\right.$ at $\left.80^{\circ} \mathrm{C}\right)$, and then the sample was reacted with 1,2-diamino-4,5-methylenedioxybenzene dihydrochloride $(\mathrm{DMB})$ for $2.5 \mathrm{~h}$ at $50^{\circ} \mathrm{C}$ in the dark. We performed HPLC analysis using a C18 reverse-phase column with fluorescence detection $373 \mathrm{~nm}$ excitation, $448 \mathrm{~nm}$ emission. Quantitation was performed using external standards with $\mathrm{N}$-glycolylneuraminic acid (Neu5Gc) and $\mathrm{N}$ acetylneuraminic acid (Neu5Ac) over 6 concentrations (0 to $250 \mathrm{ng}$ on column).

\section{RESULTS AND DISCUSSION}

\section{Clinical Outcomes from Consumption of MFGM Products}

Bovine MFGM from various commercial sources were procured for analytical testing as listed in Table 1 , several of which have been the subject of recent clinical trials. For example, a clinical trial was performed on MFGM-10 in Sweden, which reported a lower risk of otitis media (ear infection; Timby et al., 2015) and improved cognitive performance (Timby et al., 2014) at
12 mo of age among infants who received an experimental formula containing MFGM compared with infants fed standard formula. Following this trial, MFGM-10 has been added to infant formulas currently available in Sweden (BabySemp, Semper; Sundbyberg), Spain (Hero; Murcia), the United States (Enfamil Enspire, Mead Johnson Nutrition/RB), and China (Enfinitas, Mead Johnson Nutrition/RB). A study has investigated MFGM-10 as an additive to complementary food provided to Peruvian infants; decreased incidence of diarrhea, particularly bloody diarrhea, was found in the infants receiving MFGM-10 (Zavaleta et al., 2011). Another MFGM fraction, PL-20, was used in a doubleblind randomized controlled trial of healthy adults to investigate the response to Escherichia coli infection. The individuals who received PL-20 exhibited improved resistance to the attenuated $E$. coli strain, primarily in the form of stool consistency, compared with control subjects given placebo (Ten Bruggencate et al., 2016). A clinical trial on BPC-50 took place at the USDA Western Human Nutrition Research Center, which did not find any changes in bone or inflammatory markers in response to a test meal containing BPC-50 (Rogers et al., 2017). We are currently unaware of any published clinical trials related to the PLC1, BSP2, and SM2 products analyzed in this study.

\section{Lipidomics}

Previous studies have shown that the main polar lipids in MFGM, in order from largest to smallest proportion, are as follows: phosphatidylcholine (PC), SM, phosphatidylserine (PS), and phosphatidylethanolamines (PE; Argov-Argaman et al., 2013). Cholesterol, which was not detected in our untargeted analysis, is another polar lipid found in MFGM, where it helps to stabilize the bilayer (Murthy et al., 2015). Here, lipids were extracted from MFGM fractions and formula samples and subjected to LC-MS/MS. Base peak chromatograms of the commercial and formula samples in both positive and negative mode are shown in Supplemental Figure S1 (https://doi.org/10.3168/jds.2019-17179). We found excellent reproducibility across a pooled quality control sample run in technical replicate $(\mathrm{n}=4)$, with a mean coefficient of variation of $14 \%$ across all lipid species measured.

The samples were rich in both lipid diversity and abundance. A total of 338 lipid species were annotated in the extracts: 267 lipids from positive ionization mode and 71 from negative ionization mode. Positive and negative ionization species were pooled and data normalized with the value of $\log +1$. Samples were prepared based on original weight and not adjusted for lipid content. This will be reflected in the data, as the 
fat content varies substantially between the samples. Thus, the relative unadjusted compositions of the samples by lipid class, as detected using LC-MS/MS, are shown in Figure 1. Across all samples, TG dominate, whereas the diacylglycerides (DAG) are highest in the infant formulas. All other lipids are much more abundant in the MFGM samples, compared with both formulas (Figure 1). One of the defining components of MFGM, PL are hypothesized to have biological significance (Contarini and Povolo, 2013). The absence of polar lipids (sphingolipids and PL) in formula, compared with human milk, has previously been noted and the addition of PL to improve upon its formulation discussed (Cilla et al., 2016). Indeed, MFGM products are being proposed as a means to provide these polar lipids in infant formula.

The degree to which the formula samples differ from the MFGM products is displayed in the PCA graph in Figure 2. The clustering highlights that MFGM fractions are more similar to each other than the infant formulas, which are further separated in principal component 1 . The $\mathrm{PF}$ is more closely related to the MFGM than it is to the SF, and of the MFGM, SM2 is quite different from the others. Additionally, excellent clustering of the quality control samples can be seen. Because no technical replicates were performed, we cannot ascertain whether the dissimilarity is statistically significant here.

Figure 3 displays the relative percentage of each lipid class across the MFGM products. When comparing the relative composition of each MFGM product, PL is the second most abundant class (following TG), with PC being the most prominent PL. Also abundant in these samples, SM makes up at least $20 \%$ of total lipids across all MFGM samples (Figure 3). These samples have significantly more polar lipids than are found in whole milk. Previous studies of whole milk found that the lipid consists of $98.5 \%$ TG and that all of the PL combined (including SM) make up about $1 \%$, with the other $0.5 \%$ being cholesterol (Argov-Argaman et al., 2013). Thus, as expected, all of the commercial samples had higher proportions of polar lipids than are found in whole milk or the SF and PF samples.

The PCA of the MFGM samples is shown in Figure 2 and the loadings provided in Supplemental Table S1 (https://doi.org/10.3168/jds.2019-17179). The MFGM
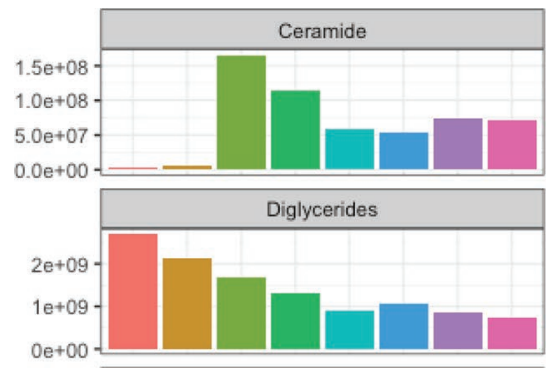

Lysophosphoethanolamnines

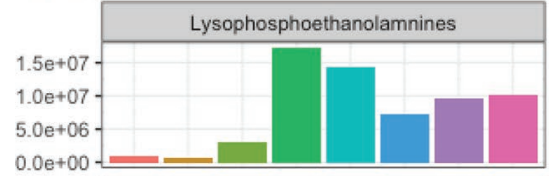

$0.0 \mathrm{e}+00-$ Glycerophosphoethanolamines

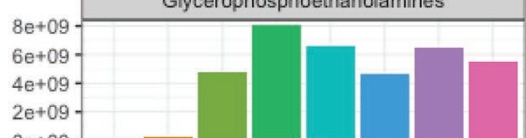

$0 \mathrm{e}+00$

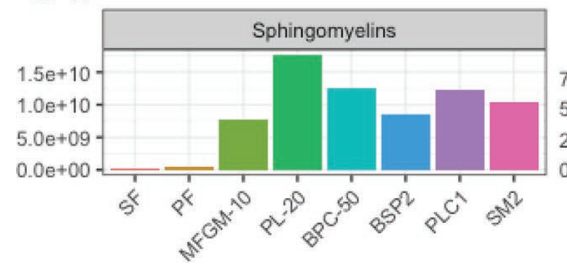

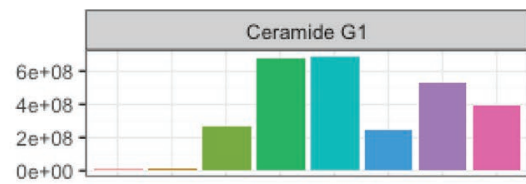
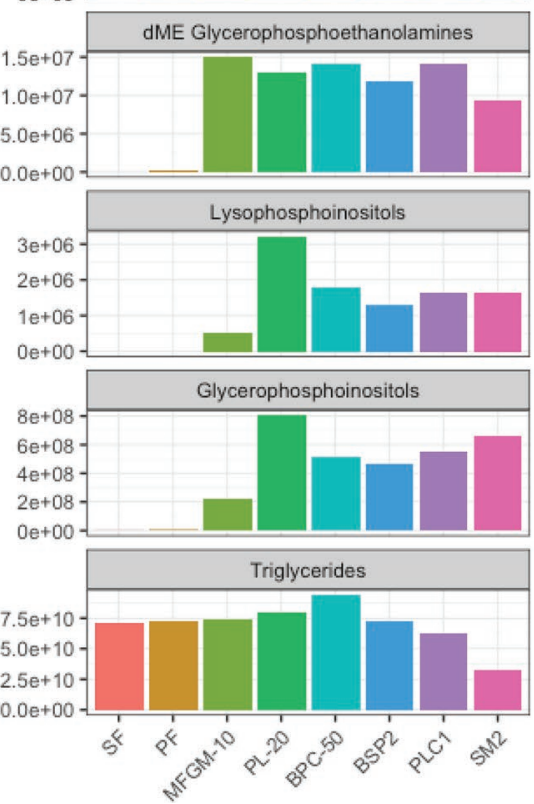
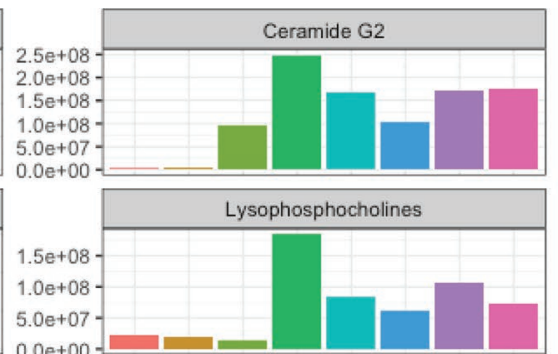

Glycerophosphocholines

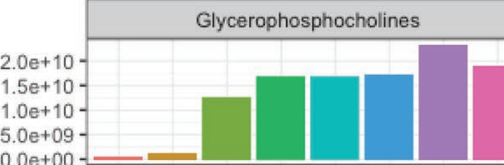

$0.0 \mathrm{e}+00$
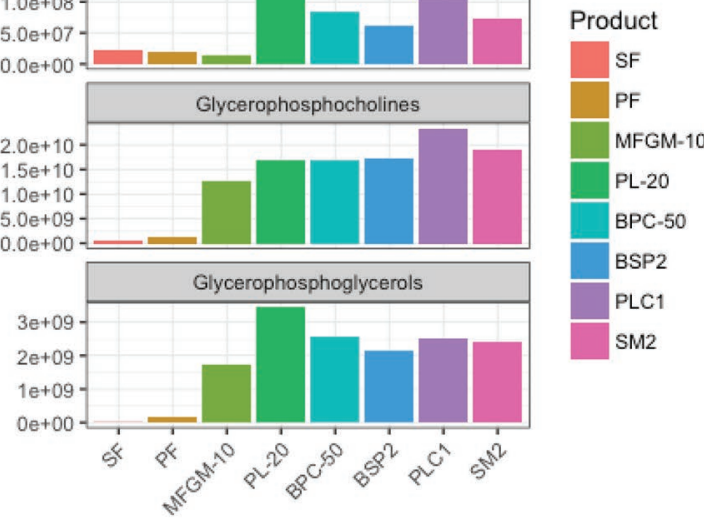

Figure 1. Peak intensity values of all samples [infant formula and milk fat globule membrane (MFGM)] by lipid class. Intensity values based

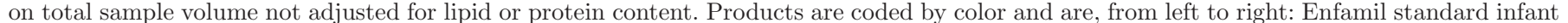
formula (SF; Mead Johnson Nutrition, Evansville, IN), Enfamil Enspire Formula (PF; Mead Johnson Nutrition), Lacprodan MFGM-10 (MFGM-

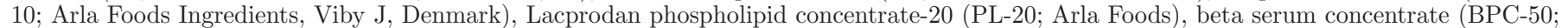

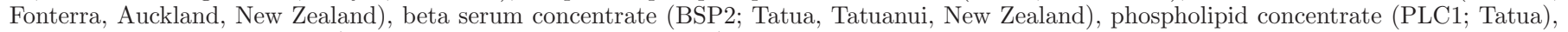
and sweet buttermilk powder (SM2; Corman, Limbourg, Belgium). The scales vary between classes, based on abundance within that class. 
ingredients all generally clustered together, with the exception of fractions being accurately marketed as different products. Additionally, the formula samples were spread away from the MFGM ingredients, with PF being less dissimilar than the SF. The top 100 PC1 lipid species are all TG, whereas $\mathrm{PC} 2$ contains a mixture of polar and non-polar lipids (data not shown). The variation between SM2 and the others is primarily explained in PC1 (TG), whereas the differences among the others are primarily explained by $\mathrm{PC} 2$, which is more driven by the PL. The top 10 PC2 lipids contain multiple PL species (phosphatidylinositol, PS, PE), ceramides, diacylglycerides, and SM.

\section{Proteomics}

The major MFGM proteins isolated from milk in the laboratory and identified through one-dimensional SDSPAGE are the following: mucin 1, xanthine dehydrogenase/oxidase (XDH), periodic acid Schiff III, cluster of differentiation (CD) 36, butyrophilin, lactadherin, adipophilin, and fatty acid binding protein (Mather, 2000). However, more recently, MS-based approaches have found MFGM proteins to be very diverse and to contain a much larger number of proteins than previously known (Affolter et al., 2010; Lu et al., 2016a). In this study, we have annotated proteins by their Uniprot designation. Thus, adipophilin is described as perilipin, whereas CD36 is platelet glycoprotein 4 .

It is important to note that different analytical techniques may result in identification of different proteins. For example, it has been reported that the bovine MFGM proteome consists of 120 proteins determined by one-dimensional electrophoresis and in-gel trypsin digestion analyzed by LC-MS/MS (Reinhardt and Lippolis, 2006). Recently, this procedure was compared, along with 5 others for MFGM protein identification (Yang et al., 2018a). They found that, although the former technique is less costly and time consuming, the suspension trapping technique (S-Trap), which is the

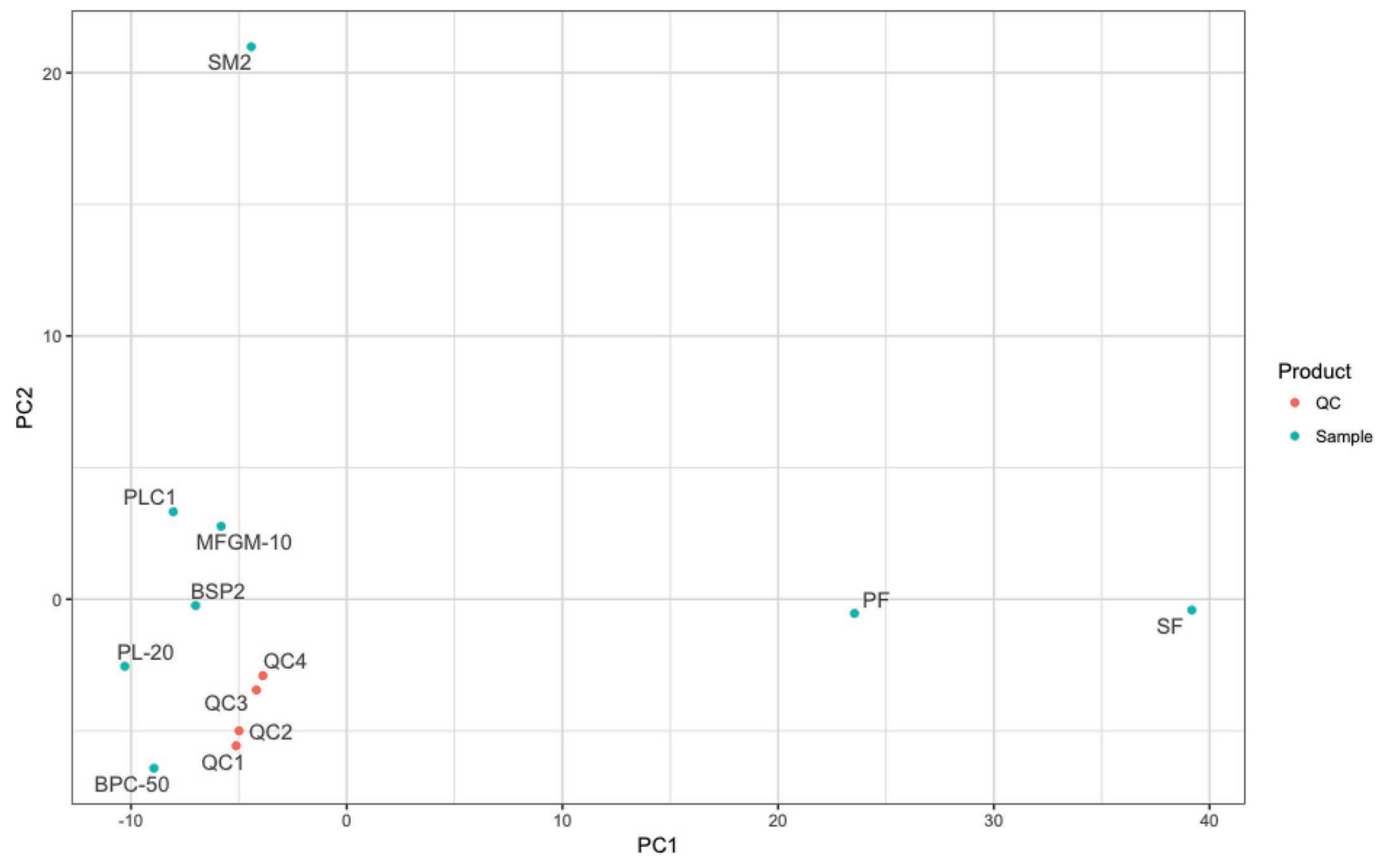

Figure 2. Principal component analysis (PC1 and 2) of lipids with pooled positive and negative ionization modes of all samples (blue) including 4 quality control samples (orange, which are composed of a pool of all the commercial samples). SF = Enfamil standard infant formula (Mead Johnson Nutrition, Evansville, IN); PF = Enfamil Enspire Formula (Mead Johnson Nutrition); MFGM-10 = Lacprodan MFGM-10 (Arla Foods Ingredients, Viby J, Denmark); PL-20 = Lacprodan phospholipid concentrate-20 (Arla Foods); BPC-50 = beta serum concentrate (Fonterra, Auckland, New Zealand); BSP2 = beta serum concentrate (Tatua, Tatuanui, New Zealand); PLC1 = phospholipid concentrate (Tatua); SM2 = sweet buttermilk powder (Corman, Limbourg, Belgium). 


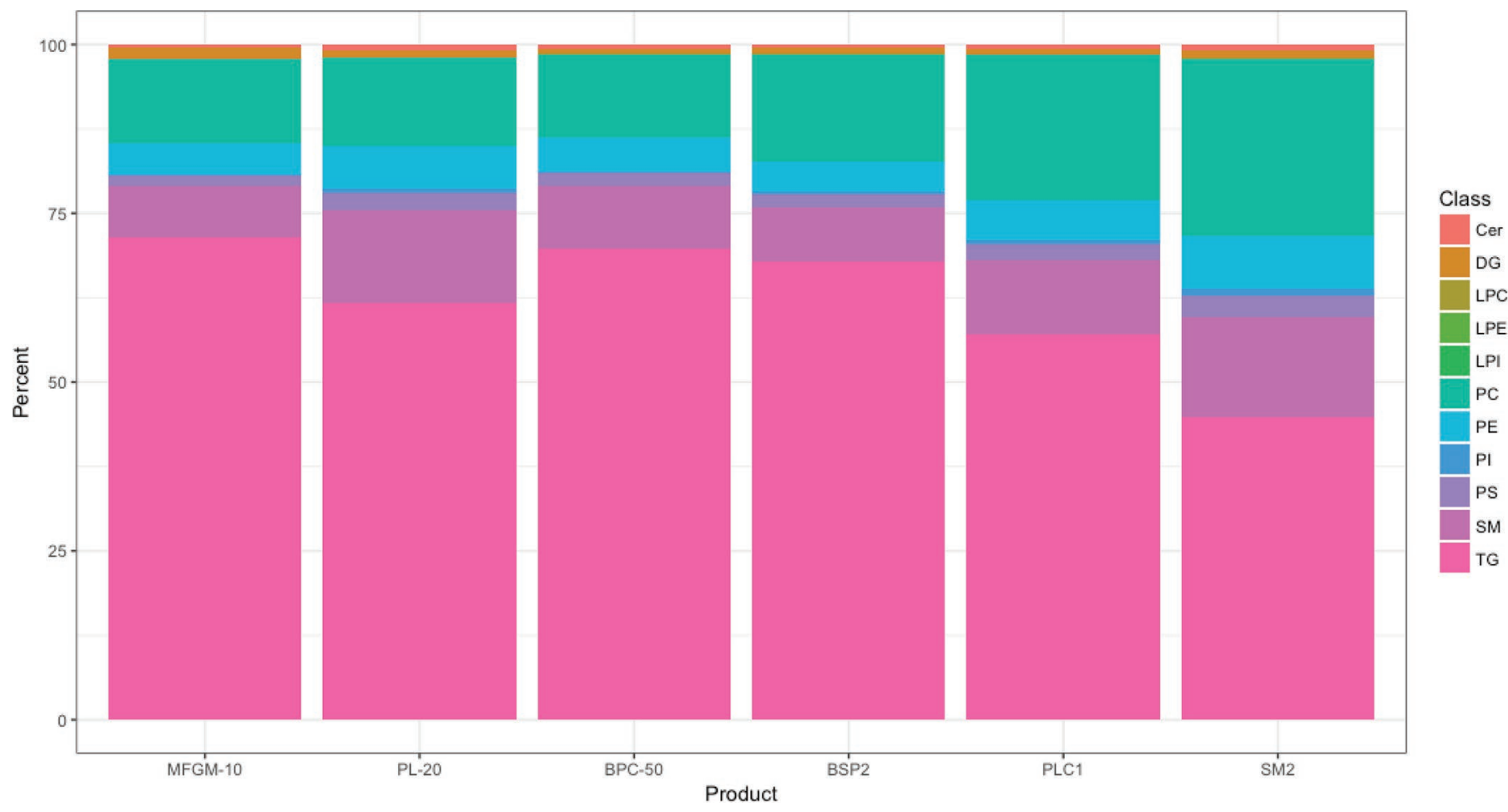

Figure 3. Relative percentage (\%) of lipids by class (positive and negative mode pooled) in milk fat globule membrane (MFGM) samples. The following classes are displayed: Cer $=$ ceramide; $\mathrm{DG}=$ diacylglyceride; $\mathrm{LPC}=$ lysophosphatidylcholine; LPE $=$ lysophosphatidylethanolamine; LPI = lysophosphatidylinositol; PC = phosphatidylcholine; PE = phosphatidylethanolamine; PI = phosphatidylinositol; PS $=$ phosphatidylserine; $\mathrm{SM}=$ sphingomyelin; TG = triglyceride. The following samples were studied: MFGM-10 = Lacprodan MFGM-10 (Arla Foods Ingredients, Viby J, Denmark); PL-20 = Lacprodan phospholipid concentrate-20 (Arla Foods); BPC-50 = beta serum concentrate (Fonterra, Auckland, New Zealand); BSP2 = beta serum concentrate (Tatua, Tatuanui, New Zealand); PLC1 = phospholipid concentrate (Tatua); SM2 = sweet buttermilk powder (Corman, Limbourg, Belgium).

method used for our proteomics analysis, along with the filter-aided sample preparation method, is able to identify the largest number of proteins. With the STrap technique, 184 proteins were identified, whereas the in-gel method identified only 41 proteins. All techniques, however, differed with regard to abundances of the identified protein, suggesting that multiple techniques are required for a robust understanding of MFGM protein composition (Yang et al., 2018a).

In the 6 commercial samples studied here, nearly 1,000 proteins were identified. Samples had varying degrees of protein diversity, and a list of the average number of proteins identified in each sample can be found in Table 1. On average, more proteins were identified in the MFGM products than in the formulas. Relative protein levels were compared across samples, and significantly different proteins are presented in Supplemental Table S2 (https://doi.org/10.3168/jds.2019-17179).

Of the MFGM fractions tested, MFGM-10 was the most different and resembled infant formula in protein composition more closely than it did other MFGM (Figure 4). This is likely because MFGM-10 is a wheybased product. Figure 5 describes the relative composi- tion of each sample compared with the infant formulas, based on their groupings into 4 protein classes: MFGM (proteins described by Mather, 2000), Milk (casein and whey), Other (likely due to processing), and Less than $1 \%$ (proteins whose individual contributions are less than $1 \%$ of the total). A detailed list of these proteins and their designation is available in Supplemental Table S3 (https://doi.org/10.3168/jds.2019-17179). From this figure, it is apparent that these fractions all contain a large amount of low-abundance proteins, together ranging from 17 to $22 \%$ of the total. Additionally, compared with the formulas, the MFGM samples are clearly enriched in MFGM proteins, as a percentage of the totals, albeit to different degrees. Although PL-20 and MFGM-10 originate from the same supplier, they are based on 2 different raw materials. We observed that PL-20 contains a higher proportion of MFGM proteins than does the MFGM-10 counterpart.

The MFGM samples exhibited a large degree of variation among them, as 364 proteins were present at significantly different levels. Within at least 1 pair, when a fold-change of 10 or greater in variation was applied, 113 proteins remained, 14 with a fold-change 
Brink et al.: OMICS ANALYSIS OF COMMERCIAL MFGM SAMPLES

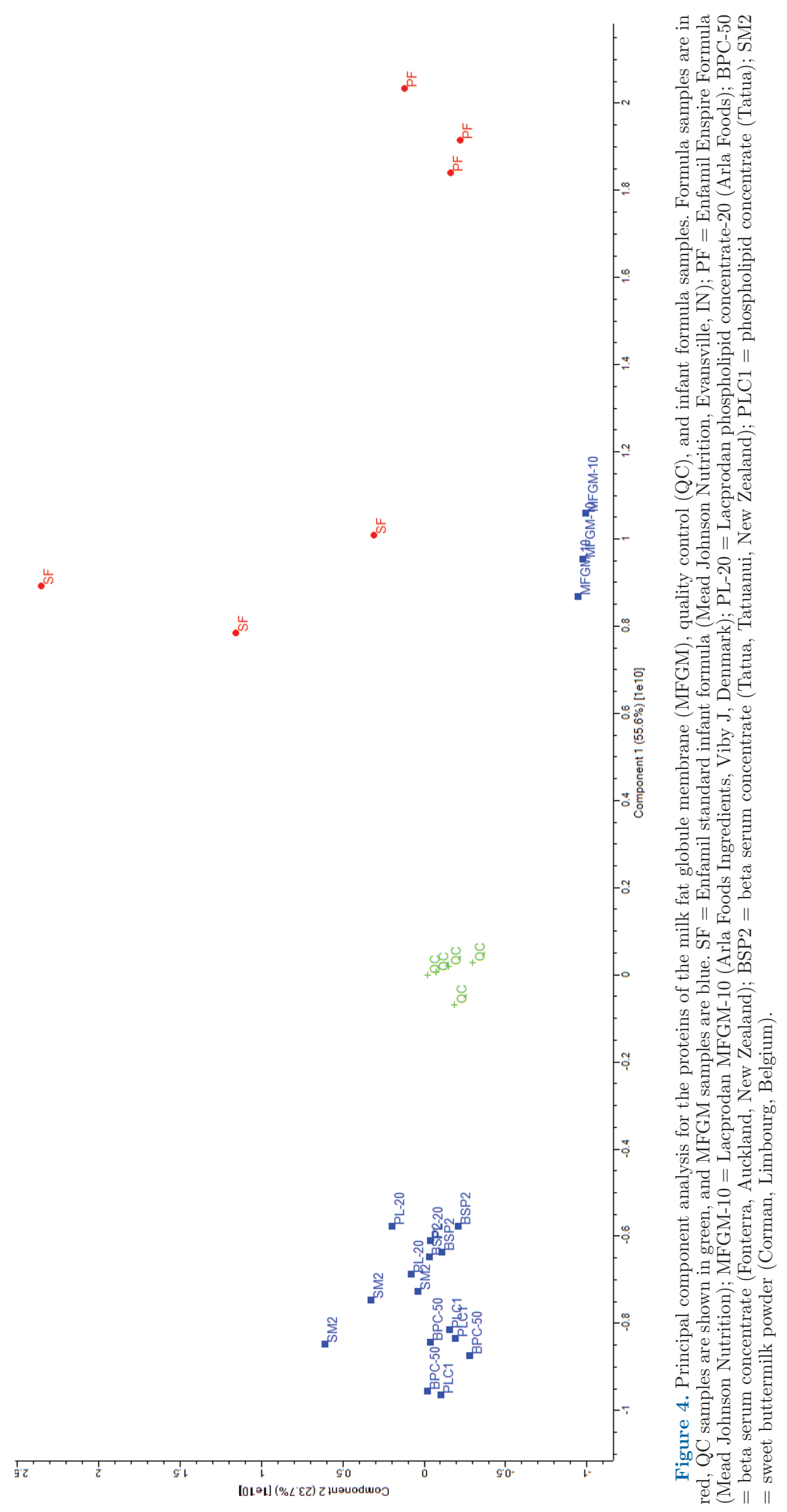


Table 2. Proteins differing in concentration by a fold-change of at least 50

\begin{tabular}{|c|c|c|}
\hline Uniprot ID & Gene symbol & Protein name \\
\hline E1BGH6 & $A C A C A$ & Acetyl-CoA carboxylase $^{1}$ \\
\hline Q8WML4 & $M U C 1$ & Mucin- $1^{1}$ \\
\hline E1B6Y3 & SCYL3 & SCY1-like pseudokinase 3 \\
\hline E1BGX8 & HHIPL2 & HHIP-like 2 \\
\hline Q32S29 & $H 2 B$ & Histone $\mathrm{H} 2 \mathrm{~B}$ \\
\hline SCPDL & $S C C P D H$ & Saccharopine dehydrogenase-like oxidoreductase \\
\hline F1N076 & $C P$ & Ceruloplasmin \\
\hline F1N4M7 & $C F I$ & Complement factor I \\
\hline BPT1 & None provided & Pancreatic trypsin inhibitor \\
\hline CASA1 & CSN1S1 & $\alpha_{\mathrm{S} 1}$ Casein \\
\hline CASA2 & CSN1S2 & $\alpha_{\mathrm{S} 2}$-Casein \\
\hline CASB & CSN2 & $\beta$-Casein \\
\hline S10A9 & S100A9 & Protein S100-A9 \\
\hline Q3ZC65 & $A U P 1$ & AUP1, lipid droplet regulating VLDL assembly factor \\
\hline
\end{tabular}

${ }^{1}$ Fold-change is 100.

of 50, and 2 with a fold-change of 100 . Table 2 displays the proteins that fell within the fold-change 50 cutoff, with the top 2 proteins also significant at a fold-change of 100 (acetyl-CoA carboxylase and mucin-1). Many of the proteins displayed in Table 2 are not traditionally defined as classical MFGM proteins, and their presence is likely a consequence of the processing techniques and raw materials used.

The literature describing the protein composition of MFGM is generally based on samples prepared via laboratory methods, using fresh milk. However, prior publications have examined the effects of processing on MFGM composition. It has been shown that milk and MFGM proteins are susceptible to lactosylation and that whey and casein proteins are increasingly incorporated into fat globules following food processing (Arena et al., 2011). More recently, a study demonstrated that pasteurization of whole milk significantly decreased the number and relative abundance of MFGM proteins found via LC-MS/MS (Yang et al., 2018b). Pasteuriza-

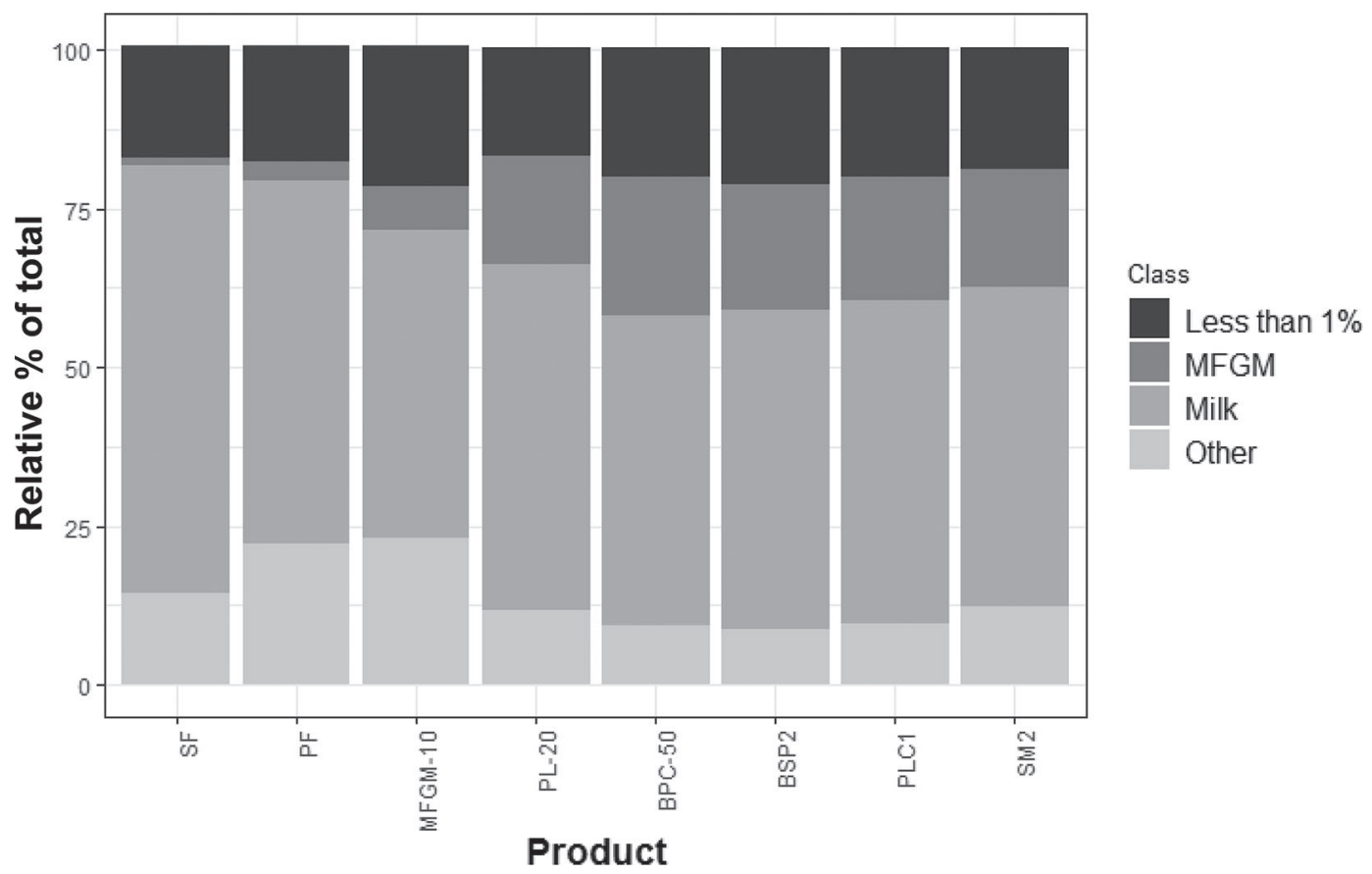

Figure 5. Proteins in each sample expressed as relative percentage of total. Class "Less than 1\%" are the proteins that individually represent less than $1 \%$ of the total. The proteins that fall in the remaining 3 classes (MFGM, Milk, and Other) each make up greater than $1 \%$ of the total $\mathrm{SF}=$ Enfamil standard infant formula (Mead Johnson Nutrition, Evansville, IN); PF = Enfamil Enspire Formula (Mead Johnson Nutrition); MFGM-10 = Lacprodan MFGM-10 (Arla Foods Ingredients, Viby J, Denmark); PL-20 = Lacprodan phospholipid concentrate-20 (Arla Foods); BPC-50 = beta serum concentrate (Fonterra, Auckland, New Zealand); BSP2 = beta serum concentrate (Tatua, Tatuanui, New Zealand); PLC1 $=$ phospholipid concentrate (Tatua); SM2 = sweet buttermilk powder (Corman, Limbourg, Belgium). 
tion performed before filtration for MFGM isolation leads to higher $\beta$-LG contamination (Hansen et al., 2018). These studies highlight that MFGM processing can significantly affect protein composition and may help further explain the variance among commercial samples.

Next, we aimed to characterize the samples by protein type. Figure 6 presents a breakdown of the different proteins by class and product. Panel (A) presents the canonical MFGM proteins, and panel (B) displays the Milk proteins. The classical MFGM protein periodic acid Schiff was not identified in any sample. According to this analysis, the MFGM-10 sample did not have the 3 classical MFGM proteins, XDH, mucin-1, and perilipin at greater than $1 \%$ (Figure $6 \mathrm{~A}$ ). With immunoblotting for $\mathrm{XDH}$, we observed higher protein levels in all MFGM fractions and PF compared with SF (Figure 7); $\mathrm{XDH}$ was observed with relative levels closer to $10 \%$. Via SDS-gel analysis, XDH has been described as a major component of the MFGM fraction - often, in fact, described as the second most dominant protein in the fraction, comprising at least $10 \%$ of the total (Mather et al., 1977; Mather, 2000). It is involved in the trafficking of the globule to the plasma membrane (Vorbach et al., 2002) and has enzymatic and anti-bacterial activities (Mather, 2000, Harrison, 2004). The MFGM-10 product also had a lower relative percentage of butyrophilin and lactadherin. For all samples, butyrophilin was shown to be less than $6 \%$ of the total, whereas it has previously been shown to comprise around $40 \%$ of the MFGM fraction (Spitsberg, 2005). We found that PLC1 also did not contain all of the major MFGM proteins, with the absence of platelet glycoprotein 4 (Figure 6A). Glycosylation-dependent adhesion molecule-1 (GLYCAM-1), previously described as a milk glycoprotein in MFGM (Dowbenko et al., 1993; Lu et al., 2016b), was present in all of the samples and was highest in PL-20 (7.2\%) and SM2 (7.7\%).

Mucin-1 has been described as a major MFGM protein in SDS gels and is 1 of the 2 proteins that fell within the 100 fold-change cutoff. Interestingly, mucin-1 was observed as a minor component of each sample, with the sample percentages as follows: 0.13 (MFGM10), 0.07 (PL-20), 0.10 (BPC-50), 0.11 (BSP2), 0.08 (PLC1), and 0.10 (SM2). Thus, although mucin-1 was highly variable between samples, it was not a major component in any of them. Through UniProt analysis, we determined that mucin- 1 and glycam- 1 contain 44 similar positions, and within these samples, glycam-1 was much more abundant. Glycam-1 thus may be filling a similar role to that of mucin-1 within these samples. $\beta$-Casein, along with $\alpha_{\mathrm{S}_{1}}$-casein and $\alpha_{\mathrm{S} 2}$-casein, falls within the 50-fold change list (Table 2), with the large degree of variability likely due to the MFGM-10 sample.
In examining the milk proteins, we can see how the MFGM-10 sample is different from the others (Figure 6B). For instance, MFGM-10 and the infant formula samples (SF and $\mathrm{PF}$ ) had larger contributions of serum albumin and immunoglobulin lambda, whereas $\mathrm{PF}$ had a greater contribution of lactotransferrin (this formula is also supplemented with lactotransferrin). We found that MFGM-10 was further distinguished by its high $\beta$-LG and low caseins $\left(\alpha_{S_{1}-}\right.$ and $\alpha_{S 2^{-}}$-casein and $\beta$-casein) content. For example, the protein $\beta$-LG (whey) composes $46 \%$ of its total protein content, whereas the remaining samples contained this protein at less than $15 \%$ (Figure 6B). $\beta$-Lactoglobulin belongs to the lipocalin protein family, a family that shares a 3-dimensional $\beta$-barrel structure (Flower et al., 2000) and has the capability to bind a variety of ligands, such as retinoic acid, retinol, vitamin D, and fatty acids (Sawyer and Kontopidis, 2000). The hydrophobic nature of $\beta$-LG may explain its affinity toward the MFGM fraction. $\beta$-Lactoglobulin is found in the whey fraction of bovine milk and not found in human milk, and $\beta$-LG peptides released during digestion have been investigated for their antioxidant, antimicrobial, opioid, antihypertensive, and hypocholesterolemic bioactivities (Hernández-Ledesma et al., 2008). Thus, further work is needed to determine how $\beta$-LG in this milk fraction may contribute to its bioactivities.

Caseins make up $80 \%$ of total protein in bovine milk, where they form micelles in solution and deliver $90 \%$ of the calcium in skim milk (Fiocchi et al., 2010). The 4 casein proteins in cow milk have distinct sequence homology, with the $\alpha_{\mathrm{S} 1}$ form found at $29 \%$ of the total, $\alpha_{\mathrm{S} 2} 8 \%$, and $\beta$-casein $27 \%$ (Fiocchi et al., 2010). In comparison, the caseins in our commercial MFGM samples were found to have the following relative abundance: $\beta$-casein less than $20 \%, \alpha_{\mathrm{S} 2}$ less than $15 \%$, and $\alpha_{\mathrm{S} 1}$ less than $11 \%$. Being the only product that originated from whey, MFGM-10 contained caseins at less than $1 \%$ of the total sample - considerably lower levels than those of the other samples (Figure 6b).

\section{Sialic Acid}

Gangliosides are a rich source of sialic acid. Sialic acid is one of the components of the commercial MFGM products believed to have neurological effects and to affect immune function (Nakano et al., 2001; Yu et al., 2012). Infant formula generally contains significantly less total sialic acid compared with human milk. Wang et al. (2001) reported that various formulas contained no more than $25 \%$ of the sialic acid found in human milk. Table 3 displays the composition of the major sialic acid-containing compounds Neu5GC and Neu5AC in the samples. Among all samples, Neu5AC was more abun- 
dant than Neu5GC. Levels of Neu5GC in bovine milk have been shown to vary according to stage of lactation, with higher concentrations early in lactation, whereas human milk has been shown to contain predominantly Neu5AC (Wu et al., 2018). The predominant gangliosides in milk, $\mathrm{GM}_{3}$ and $\mathrm{GD}_{3}$, are composed of Neu5AC attached to a sphingosine backbone (Perea-Sanz et al., 2017). Thus, the dominance of Neu5AC is likely due to the presence of gangliosides in the MFGM fractions, and the higher proportion more closely mirrors that of human milk. However, because the filtration processes of these products are proprietary, the mechanisms by which this occurs are unknown. The MFGM-10 sample had the highest percentage of both compounds; conversely, SM2 had the lowest percentage. This observation, however, could not be subjected to statistical testing, as technical replicates were not performed.

\section{CONCLUSIONS}

The commercial MFGM products investigated all contain the main MFGM ingredients: polar lipids, pro- teins, and sialic acid. The concentrations of each component differed considerably among the products. In our analysis, we were able only to statistically test for differences in protein, and large differences in protein composition were found. Being the only whey-based product, MFGM-10 stood out from the other fractions. It contained less MFGM protein per weight and a greater contribution of whey proteins. Additionally, the abundance of the main lipids and percentage of sialic acid were variable among samples. Despite a lack of statistical analysis to determine differences between lipid samples, the composition of lipids was more variable than that of proteins among fractions, and this was in agreement with the various descriptions of the products (i.e., bovine serum vs. PL fractions). We suggest that general guidelines to describe the composition of MFGM should be established and that the components within these fractions be made transparent. The current literature on MFGM contains research using different MFGM products, which, as demonstrated here, contain varying levels of components. Thus, it is imperative for researchers to clearly identify and pres-

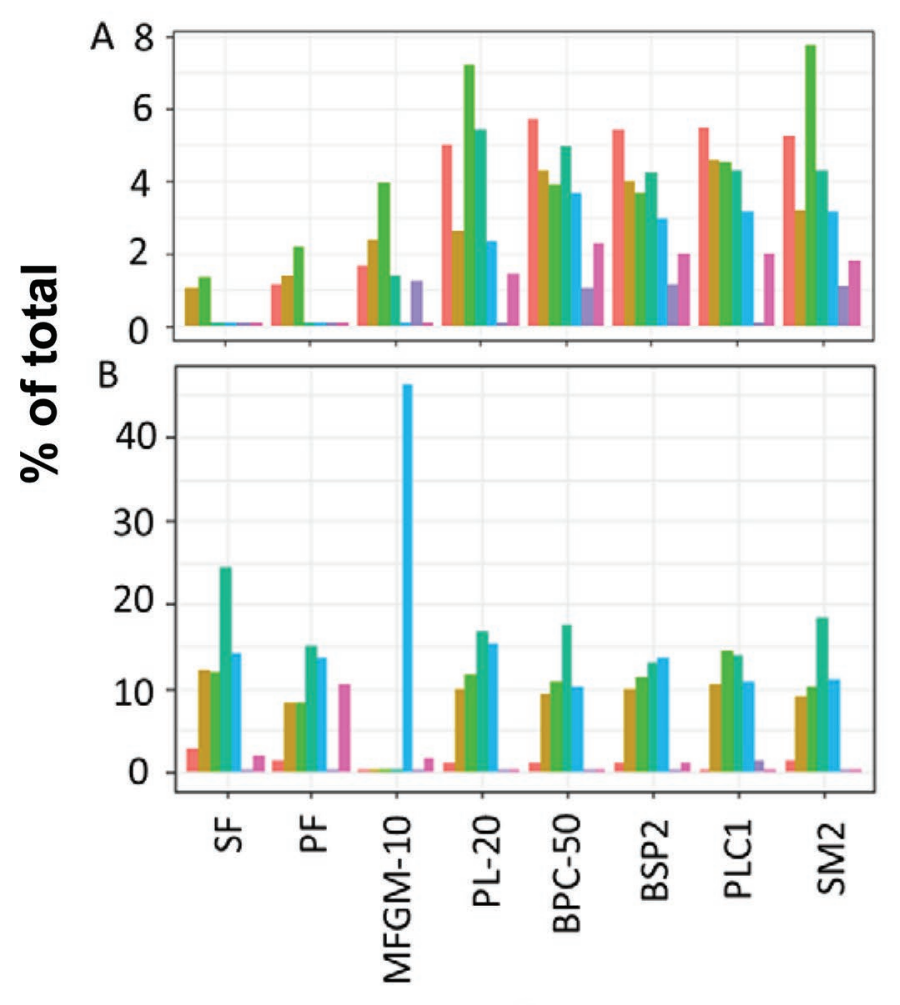

MFGM protein

Butyrophilin

Fatty acid-binding protein

Glycosylation-dependent cell adhesion molecule 1

Lactadherin

Perilipin

Platelet glycoprotein 4

Xanthine dehydrogenase/oxidase

Milk protein

a-Lactalbumin

a-S1-casein

a-S2-casein

$\beta$-Casein

$\beta$-Lactoglobulin

$\mathrm{K}$-Casein

Xanthine dehydrogenase/oxidase

\section{Product}

Figure 6. Relative percentages of the milk fat globule membrane (MFGM) (A) and milk (B) proteins by sample. SF = Enfamil standard infant formula (Mead Johnson Nutrition, Evansville, IN); PF = Enfamil Enspire Formula (Mead Johnson Nutrition); MFGM-10 = Lacprodan MFGM-10 (Arla Foods Ingredients, Viby J, Denmark); PL-20 = Lacprodan phospholipid concentrate-20 (Arla Foods); BPC-50 = beta serum concentrate (Fonterra, Auckland, New Zealand); BSP2 = beta serum concentrate (Tatua, Tatuanui, New Zealand); PLC1 = phospholipid concentrate (Tatua); SM2 = sweet buttermilk powder (Corman, Limbourg, Belgium). 
Table 3. Sialic acid (Neu5GC or Neu5AC) analysis of commercial milk fat globule membrane (MFGM) samples

\begin{tabular}{lcccc}
\hline Item $^{1}$ & $\begin{array}{c}\text { Neu5GC, } \\
\mathrm{mg} / \mathrm{g}\end{array}$ & $\begin{array}{c}\text { Neu5AC, } \\
\mathrm{mg} / \mathrm{g}\end{array}$ & Neu5GC, $\%$ & Neu5AC, \% \\
\hline MFGM-10 & 1.27 & 25.2 & 0.13 & 2.52 \\
PL-20 & 0.23 & 11.1 & 0.02 & 1.12 \\
BPC-50 & 0.25 & 11.3 & 0.02 & 1.13 \\
BSP2 & 0.22 & 10.4 & 0.02 & 1.22 \\
PLC1 & 0.28 & 12.2 & 0.03 & 0.66 \\
SM2 & 0.14 & 6.56 & 0.01 & \\
\hline
\end{tabular}

${ }^{1}$ MFGM-10 = Lacprodan MFGM-10 (Arla Foods Ingredients, Viby J, Denmark); PL-20 = Lacprodan phospholipid concentrate-20 (Arla Foods): BPC-50 = beta serum concentrate; BSP2 = beta serum concentrate (Tatua, Tatuanui, New Zealand); PLC1 = phospholipid concentrate (Tatua); SM2 = sweet buttermilk powder (Corman, Limbourg, Belgium).

ent the ingredients, so that clinical studies can be properly evaluated and products can be specifically tailored to those represented in the scientific literature.

\section{ACKNOWLEDGMENTS}

The authors thank Chengao Zhu (University of California, Davis) for his assistance with visualizing and analyzing the lipidomics data in R, and Heike Schwendel (Grasslands Research Centre, Palmerston North, New Zealand) for assistance in the lipidomic analysis. Lipidomic and sialic acid analysis were funded by the

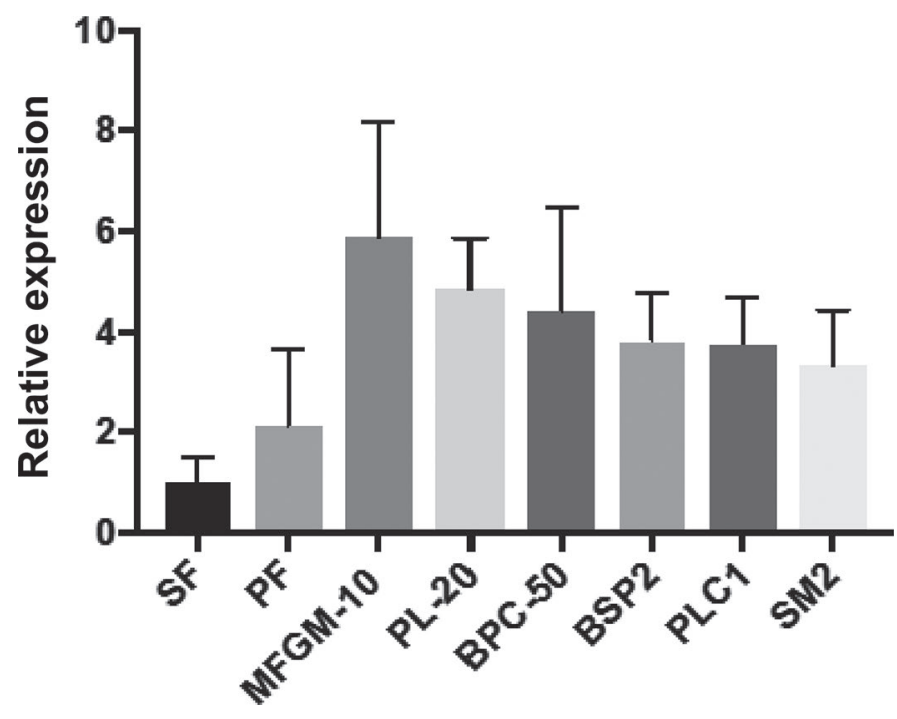

Figure 7. Immunoblotting percentage of xanthine dehydrogenase determined by stain-free method total protein per lane. All samples are shown relative to standard infant formula $(\mathrm{SF}) . \mathrm{SF}=$ Enfamil standard infant formula (Mead Johnson Nutrition, Evansville, IN); PF $=$ Enfamil Enspire Formula (Mead Johnson Nutrition); MFGM-10 = Lacprodan MFGM-10 (Arla Foods Ingredients, Viby J, Denmark); PL20 = Lacprodan phospholipid concentrate-20 (Arla Foods); BPC-50 = beta serum concentrate (Fonterra, Auckland, New Zealand); BSP2 = beta serum concentrate (Tatua, Tatuanui, New Zealand); PLC1 = phospholipid concentrate (Tatua); SM2 = sweet buttermilk powder (Corman, Limbourg, Belgium). Error bars indicate SEM.
AgResearch Strategic Science Investment fund, Food Nutrition. LRB and BLL were responsible for the study design. Proteomics work and analysis were performed by AWH. Lipidomics was performed by $\mathrm{KF}$ and $\mathrm{KW}$. Sialic acid analysis was performed by MA, and immunoblotting by SM. LRB and BLL had primary roles in manuscript preparation; however, all authors reviewed and approved the final draft. Bo Lönnerdal has served as a consultant for Mead Johnson Nutrition and Arla Foods.

\section{REFERENCES}

Affolter, M., L. Grass, F. Vanrobaeys, B. Casado, and M. Kussmann. 2010. Qualitative and quantitative profiling of the bovine milk fat globule membrane proteome. J. Proteomics 73:1079-1088. https:/ /doi.org/10.1016/j.jprot.2009.11.008.

Arena, S., G. Renzone, G. Novi, and A. Scaloni. 2011. Redox proteomics of fat globules unveils broad protein lactosylation and compositional changes in milk samples subjected to various technological procedures. J. Proteomics 74:2453-2475. https://doi .org/10.1016/j.jprot.2011.01.002.

Argov-Argaman, N., K. Mida, B. C. Cohen, M. Visker, and K. Hettinga. 2013. Milk fat content and DGAT1 genotype determine lipid composition of the milk fat globule membrane. PLoS One 8:e68707. https://doi.org/10.1371/journal.pone.0068707.

Billeaud, C., G. Puccio, E. Saliba, B. Guillois, C. Vaysse, S. Pecquet, and P. Steenhout. 2014. Safety and tolerance evaluation of milk fat globule membrane-enriched infant formulas: A randomized controlled multicenter non-inferiority trial in healthy term infants. Clin. Med. Insights. Pediatr. 8:51-60. https://doi.org/10.4137/ CMPed.S16962.

Brink, L. R., J. P. Gueniot, and B. Lönnerdal. 2019. Effects of milk fat globule membrane and its various components on neurologic development in a postnatal growth restriction rat model. J. Nutr. Biochem. 69:163-171. https://doi.org/10.1016/j.jnutbio.2019.03.013.

Brink, L. R., and B. Lönnerdal. 2018. The role of milk fat globule membranes in behavior and cognitive function using a suckling rat pup supplementation model. J. Nutr. Biochem. 58:131-137. https: //doi.org/10.1016/j.jnutbio.2018.05.004.

Bu, H. F., X. L. Zuo, X. Wang, M. A. Ensslin, V. Koti, W. Hsueh, A. S. Raymond, B. D. Shur, and X. D. Tan. 2007. Milk fat globuleEGF factor 8/lactadherin plays a crucial role in maintenance and repair of murine intestinal epithelium. J. Clin. Invest. 117:36733683. https://doi.org/10.1172/JCI31841.

Cilla, A., K. Diego Quintaes, R. Barbera, and A. Alegria. 2016. Phospholipids in human milk and infant formulas: Benefits and needs for correct infant nutrition. Crit. Rev. Food Sci. Nutr. 56:18801892. https://doi.org/10.1080/10408398.2013.803951. 
Contarini, G., and M. Povolo. 2013. Phospholipids in milk fat: Composition, biological and technological significance, and analytical strategies. Int. J. Mol. Sci. 14:2808-2831. https://doi.org/10.3390/ ijms14022808.

Dewettinck, K., R. Rombaut, N. Thienpont, T. T. Le, K. Messens, and J. Van Camp. 2008. Nutritional and technological aspects of milk fat globule membrane material. Int. Dairy J. 18:436-457. https:// doi.org/10.1016/j.idairyj.2007.10.014.

Dowbenko, D., A. Kikuta, C. Fennie, N. Gillett, and L. A. Lasky. 1993. Glycosylation-dependent cell adhesion molecule 1 (GlyCAM 1) mucin is expressed by lactating mammary gland epithelial cells and is present in milk. J. Clin. Invest. 92:952-960. https://doi.org/ $10.1172 /$ JCI116671.

Fiocchi, A., J. Brozek, H. Schunemann, S. L. Bahna, A. von Berg, K. Beyer, M. Bozzola, J. Bradsher, E. Compalati, M. Ebisawa, M. A. Guzman, H. Li, R. G. Heine, P. Keith, G. Lack, M. Landi, A. Martelli, F. Rance, H. Sampson, A. Stein, L. Terracciano, S. Vieths, and World Allergy Organization (WAO) Special Committee on Food Allergy. 2010. World Allergy Organization (WAO) Diagnosis and Rationale for Action against Cow's Milk Allergy (DRACMA) guidelines. Pediatr. Allergy Immunol. 21(Suppl. 21):1-125. https:/ /doi.org/10.1111/j.1399-3038.2010.01068.x.

Flower, D. R., A. C. North, and C. E. Sansom. 2000. The lipocalin protein family: Structural and sequence overview. Biochim. Biophys. Acta 1482:9-24. https://doi.org/10.1016/S0167-4838(00)00148-5.

Fuller, K. L., T. B. Kuhlenschmidt, M. S. Kuhlenschmidt, R. JimenezFlores, and S. M. Donovan. 2013. Milk fat globule membrane isolated from buttermilk or whey cream and their lipid components inhibit infectivity of rotavirus in vitro. J. Dairy Sci. 96:3488-3497. https://doi.org/10.3168/jds.2012-6122.

Gurnida, D. A., A. M. Rowan, P. Idjradinata, D. Muchtadi, and N. Sekarwana. 2012. Association of complex lipids containing gangliosides with cognitive development of 6-month-old infants. Early Hum. Dev. 88:595-601. https://doi.org/10.1016/j.earlhumdev.2012 .01 .003 .

Hansen, S. F., B. Petrat-Melin, J. T. Rasmussen, L. B. Larsen, M. S. Ostenfeld, and L. Wiking. 2018. Placing pasteurisation before or after microfiltration impacts the protein composition of milk fat globule membrane material. Int. Dairy J. 81:35-41. https://doi .org/10.1016/j.idairyj.2017.12.015.

Hari, S., R. Ochiai, Y. Shioya, and Y. Katsuragi. 2015. Safety evaluation of the consumption of high dose milk fat globule membrane in healthy adults: A double-blind, randomized controlled trial with parallel group design. Biosci. Biotechnol. Biochem. 79:1172-1177. https://doi.org/10.1080/09168451.2015.1012150.

Harrison, R. 2004. Physiological roles of xanthine oxidoreductase. Drug Metab. Rev. 36:363-375. https://doi.org/10.1081/DMR -120037569 .

Hernández-Ledesma, B., I. Recio, and L. Amigo. 2008. Beta-lactoglobulin as source of bioactive peptides. Amino Acids 35:257-265. https://doi.org/10.1007/s00726-007-0585-1.

Hernell, O., N. Timby, M. Domellöf, and B. Lönnerdal. 2016. Clinical benefits of milk fat globule membranes for infants and children. J. Pediatr. 173(Suppl.):S60-S65. https://doi.org/10.1016/j.jpeds 2016.02.077.

Hester, S. N., X. Chen, M. Li, M. H. Monaco, S. S. Comstock, T. B. Kuhlenschmidt, M. S. Kuhlenschmidt, and S. M. Donovan. 2013. Human milk oligosaccharides inhibit rotavirus infectivity in vitro and in acutely infected piglets. Br. J. Nutr. 110:1233-1242. https: //doi.org/10.1017/S0007114513000391.

Higurashi, S., Y. Haruta-Ono, H. Urazono, T. Kobayashi, and Y. Kadooka. 2015. Improvement of skin condition by oral supplementation with sphingomyelin-containing milk phospholipids in a double-blind, placebo-controlled, randomized trial. J. Dairy Sci. 98:6706-6712. https://doi.org/10.3168/jds.2015-9529.

Idota, T., H. Kawakami, Y. Murakami, and M. Sugawara. 1995. Inhibition of cholera toxin by human milk fractions and sialyllactose. Biosci. Biotechnol. Biochem. 59:417-419. https://doi.org/10.1271/ bbb.59.417.

Kim, H., T. Suzuki, M. Kim, N. Kojima, N. Ota, A. Shimotoyodome, T. Hase, E. Hosoi, and H. Yoshida. 2015. Effects of exercise and milk fat globule membrane (MFGM) supplementation on body composition, physical function, and hematological parameters in community-dwelling frail Japanese women: A randomized double blind, placebo-controlled, follow-up trial. PLoS One 10:e0116256. https://doi.org/10.1371/journal.pone.0116256.

Kvistgaard, A. S., L. T. Pallesen, C. F. Arias, S. Lopez, T. E. Petersen, C. W. Heegaard, and J. T. Rasmussen. 2004. Inhibitory effects of human and bovine milk constituents on rotavirus infections. J. Dairy Sci. 87:4088-4096. https://doi.org/10.3168/jds S0022-0302(04)73551-1.

Liu, B., Z. Yu, C. Chen, D. E. Kling, and D. S. Newburg. 2012. Human milk mucin 1 and mucin 4 inhibit Salmonella enterica serovar Typhimurium invasion of human intestinal epithelial cells in vitro. J. Nutr. 142:1504-1509. https://doi.org/10.3945/jn.111.155614.

Lu, J., N. Argov-Argaman, J. Anggrek, S. Boeren, T. van Hooijdonk, J. Vervoort, and K. A. Hettinga. 2016a. The protein and lipid composition of the membrane of milk fat globules depends on their size. J. Dairy Sci. 99:4726-4738. https://doi.org/10.3168/jds.2015 -10375 .

Lu, J., X. Wang, W. Zhang, L. Liu, X. Pang, S. Zhang, and J. Lv. 2016b. Comparative proteomics of milk fat globule membrane in different species reveals variations in lactation and nutrition. Food Chem. 196:665-672. https://doi.org/10.1016/j.foodchem.2015.10 .005 .

Martin, H. M., J. T. Hancock, V. Salisbury, and R. Harrison. 2004. Role of xanthine oxidoreductase as an antimicrobial agent. Infect. Immun. 72:4933-4939. https://doi.org/10.1128/IAI.72.9.4933 -4939.2004 .

Martín, M. J., E. Vazquez, and R. Rueda. 2007. Application of a sensitive fluorometric HPLC assay to determine the sialic acid content of infant formulas. Anal. Bioanal. Chem. 387:2943-2949. https:// doi.org/10.1007/s00216-007-1160-z.

Martini, M., F. Salari, and I. Altomonte. 2016. The macrostructure of milk lipids: The fat globules. Crit. Rev. Food Sci. Nutr. 56:12091221. https://doi.org/10.1080/10408398.2012.758626.

Mather, I. H. 2000. A review and proposed nomenclature for major proteins of the milk-fat globule membrane. J. Dairy Sci. 83:203247. https://doi.org/10.3168/jds.S0022-0302(00)74870-3.

Mather, I. H., K. Weber, and T. W. Keenan. 1977. Membranes of mammary gland. XII. Loosely associated proteins and compositional heterogeneity of bovine milk fat globule membrane. J. Dairy Sci. 60:394-402. https://doi.org/10.3168/jds.S0022-0302(77)83878 -2 .

McJarrow, P., N. Schnell, J. Jumpsen, and T. Clandinin. 2009. Influence of dietary gangliosides on neonatal brain development. Nutr. Rev. 67:451-463. https://doi.org/10.1111/j.1753-4887.2009.00211 .x.

Minegishi, Y., N. Ota, S. Soga, and A. Shimotoyodome. 2016. Effects of nutritional supplementation with milk fat globule membrane on physical and muscle function in healthy adults aged 60 and over with semiweekly light exercise: A randomized double-blind, placebo-controlled pilot trial. J. Nutr. Sci. Vitaminol. (Tokyo) 62:409-415. https://doi.org/10.3177/jnsv.62.409.

Moukarzel, S., R. A. Dyer, C. Garcia, A. M. Wiedeman, G. Boyce, J. Weinberg, B. O. Keller, R. Elango, and S. M. Innis. 2018. Milk fat globule membrane supplementation in formula-fed rat pups improves reflex development and may alter brain lipid composition. Sci. Rep. 8:15277. https://doi.org/10.1038/s41598-018-33603-8.

Mudd, A. T., L. S. Alexander, K. Berding, R. V. Waworuntu, B. M. Berg, S. M. Donovan, and R. N. Dilger. 2016. Dietary prebiotics, milk fat globule membrane, and lactoferrin affects structural neurodevelopment in the young piglet. Front Pediatr. 4:4. https://doi .org/10.3389/fped.2016.00004.

Murthy, A. V., F. Guyomarc'h, G. Paboeuf, V. Vié, and C. Lopez. 2015. Cholesterol strongly affects the organization of lipid monolayers studied as models of the milk fat globule membrane: Condensing effect and change in the lipid domain morphology. Biochim. Biophys. Acta 1848:2308-2316. https://doi.org/10.1016/j .bbamem.2015.06.014. 
Nakano, T., M. Sugawara, and H. Kawakami. 2001. Sialic acid in human milk: Composition and functions. Acta Paediatrica Taiwanica 42:11-17.

Novakovic, P., C. Charavaryamath, I. Moshynskyy, B. Lockerbie, R. S. Kaushik, M. E. Loewen, B. A. Kidney, C. Stuart, and E. Simko. 2015. Evaluation of inhibition of F4ac positive Escherichia coli attachment with xanthine dehydrogenase, butyrophilin, lactadherin and fatty acid binding protein. BMC Vet. Res. 11:238. https://doi .org/10.1186/s12917-015-0528-0.

Oshida, K., T. Shimizu, M. Takase, Y. Tamura, T. Shimizu, and Y. Yamashiro. 2003. Effects of dietary sphingomyelin on central nervous system myelination in developing rats. Pediatr. Res. 53:589593. https://doi.org/10.1203/01.PDR.0000054654.73826.AC.

Otnaess, A. B., A. Laegreid, and K. Ertresvag. 1983. Inhibition of enterotoxin from Escherichia coli and Vibrio cholerae by gangliosides from human milk. Infect. Immun. 40:563-569.

Palmano, K., A. Rowan, R. Guillermo, J. Guan, and P. McJarrow. 2015. The role of gangliosides in neurodevelopment. Nutrients 7:3891-3913. https://doi.org/10.3390/nu7053891.

Perea-Sanz, L., G. Garcia-Llatas, and M. J. Lagarda. 2017. Gangliosides in human milk and infant formula: A review on analytical techniques and contents. Food Rev. Int. 34:511-538. https://doi .org/10.1080/87559129.2017.1347671.

Poppitt, S. D., R. A. McGregor, K. R. Wiessing, V. K. Goyal, A. J. Chitkara, S. Gupta, K. Palmano, B. Kuhn-Sherlock, and M. A. McConnell. 2014. Bovine complex milk lipid containing gangliosides for prevention of rotavirus infection and diarrhoea in northern Indian infants. J. Pediatr. Gastroenterol. Nutr. 59:167-171. https://doi.org/10.1097/MPG.0000000000000398.

Reinhardt, T. A., and J. D. Lippolis. 2006. Bovine milk fat globule membrane proteome. J. Dairy Res. 73:406-416. https://doi.org/10 $.1017 /$ S0022029906001889.

Rogers, T. S., E. Demmer, N. Rivera, E. R. Gertz, J. B. German, J. T. Smilowitz, A. M. Zivkovic, and M. D. Van Loan. 2017. The role of a dairy fraction rich in milk fat globule membrane in the suppression of postprandial inflammatory markers and bone turnover in obese and overweight adults: An exploratory study. Nutr. Metab. (Lond.) 14:36. https://doi.org/10.1186/s12986-017-0189-z.

Rosqvist, F., A. Smedman, H. Lindmark-Mansson, M. Paulsson, P. Petrus, S. Straniero, M. Rudling, I. Dahlman, and U. Riserus. 2015. Potential role of milk fat globule membrane in modulating plasma lipoproteins, gene expression, and cholesterol metabolism in humans: A randomized study. Am. J. Clin. Nutr. 102:20-30. https://doi.org/10.3945/ajcn.115.107045.

Sawyer, L., and G. Kontopidis. 2000. The core lipocalin, bovine betalactoglobulin. Biochim. Biophys. Acta 1482:136-148. https://doi .org/10.1016/S0167-4838(00)00160-6.

Schipper, L., G. van Dijk, L. M. Broersen, M. Loos, N. Bartke, A. J. Scheurink, and E. M. van der Beek. 2016. A postnatal diet containing phospholipids, processed to yield large, phospholipidcoated lipid droplets, affects specific cognitive behaviors in healthy male mice. J. Nutr. 146:1155-1161. https://doi.org/10.3945/jn.115 224998 .

Smith, C. A., E. J. Want, G. O'Maille, R. Abagyan, and G. Siuzdak. 2006. XCMS: Processing mass spectrometry data for metabolite profiling using nonlinear peak alignment, matching, and identification. Anal. Chem. 78:779-787. https://doi.org/10.1021/ac051437y.

Soga, S., N. Ota, and A. Shimotoyodome. 2015. Dietary milk fat globule membrane supplementation combined with regular exercise improves skeletal muscle strength in healthy adults: A randomized double-blind, placebo-controlled, crossover trial. Nutr. J. 14:85. https://doi.org/10.1186/s12937-015-0073-5.

Spitsberg, V. L. 2005. Invited review: Bovine milk fat globule membrane as a potential nutraceutical. J. Dairy Sci. 88:2289-2294. https://doi.org/10.3168/jds.S0022-0302(05)72906-4.

Stevens, C. R., T. M. Millar, J. G. Clinch, J. M. Kanczler, T. Bodamyali, and D. R. Blake. 2000. Antibacterial properties of xanthine oxidase in human milk. Lancet 356:829-830. https://doi.org/10 .1016/S0140-6736(00)02660-X.
Tanaka, K., M. Hosozawa, N. Kudo, N. Yoshikawa, K. Hisata, H. Shoji, K. Shinohara, and T. Shimizu. 2013. The pilot study: Sphingomyelin-fortified milk has a positive association with the neurobehavioural development of very low birth weight infants during infancy, randomized control trial. Brain Dev. 35:45-52. https://doi .org/10.1016/j.braindev.2012.03.004.

Ten Bruggencate, S. J., P. D. Frederiksen, S. M. Pedersen, E. G. Floris-Vollenbroek, E. Lucas-van de Bos, E. van Hoffen, and P. L. Wejse. 2016. Dietary milk-fat-globule membrane affects resistance to diarrheagenic Escherichia coli in healthy adults in a randomized, placebo-controlled, double-blind study. J. Nutr. 146:249-255. https://doi.org/10.3945/jn.115.214098.

Timby, N., E. Domellöf, O. Hernell, B. Lönnerdal, and M. Domellöf 2014. Neurodevelopment, nutrition, and growth until 12 mo of age in infants fed a low-energy, low-protein formula supplemented with bovine milk fat globule membranes: A randomized controlled trial. Am. J. Clin. Nutr. 99:860-868. https://doi.org/10.3945/ajcn .113 .064295

Timby, N., O. Hernell, O. Vaarala, M. Melin, B. Lönnerdal, and M. Domellöf. 2015. Infections in infants fed formula supplemented with bovine milk fat globule membranes. J. Pediatr. Gastroenterol. Nutr. 60:384-389. https://doi.org/10.1097/MPG .0000000000000624 .

Veereman-Wauters, G., S. Staelens, R. Rombaut, K. Dewettinck, D. Deboutte, R. J. Brummer, M. Boone, and P. Le Ruyet. 2012. Milk fat globule membrane (INPULSE) enriched formula milk decreases febrile episodes and may improve behavioral regulation in young children. Nutrition 28:749-752. https://doi.org/10.1016/j.nut.2011 .10 .011 .

Vorbach, C., A. Scriven, and M. R. Capecchi. 2002. The housekeeping gene xanthine oxidoreductase is necessary for milk fat droplet enveloping and secretion: Gene sharing in the lactating mammary gland. Genes Dev. 16:3223-3235. https://doi.org/10.1101/gad 1032702 .

Wang, B., J. Brand-Miller, P. McVeagh, and P. Petocz. 2001. Concentration and distribution of sialic acid in human milk and infant formulas. Am. J. Clin. Nutr. 74:510-515. https://doi.org/10.1093/ ajcn/74.4.510.

Wu, X., R. T. Jackson, S. A. Khan, J. Ahuja, and P. R. Pehrsson. 2018. Human milk nutrient composition in the United States: Current knowledge, challenges, and research needs. Curr. Dev. Nutr. 2:nzy025. https://doi.org/10.1093/cdn/nzy025.

Yang, Y., E. Anderson, and S. Zhang. 2018a. Evaluation of six sample preparation procedures for qualitative and quantitative proteomics analysis of milk fat globule membrane. Electrophoresis 39:23322339. https://doi.org/10.1002/elps.201800042.

Yang, Y., N. Zheng, X. Zhao, J. Yang, Y. Zhang, R. Han, Y. Qi, S. Zhao, S. Li, F. Wen, T. Guo, C. Zang, and J. Wang. 2018b. Changes in bovine milk fat globule membrane proteins caused by heat procedures using a label-free proteomic approach. Food Res. Int. 113:1-8. https://doi.org/10.1016/j.foodres.2018.06.046.

Yu, R. K., Y. T. Tsai, and T. Ariga. 2012. Functional roles of gangliosides in neurodevelopment: An overview of recent advances. Neurochem. Res. 37:1230-1244. https://doi.org/10.1007/s11064 -012-0744-y.

Zavaleta, N., A. S. Kvistgaard, G. Graverholt, G. Respicio, H. Guija, N. Valencia, and B. Lönnerdal. 2011. Efficacy of an MFGM-enriched complementary food in diarrhea, anemia, and micronutrient status in infants. J. Pediatr. Gastroenterol. Nutr. 53:561-568.

\section{ORCIDS}

Lauren R. Brink @ https://orcid.org/0000-0003-0191-5168 Shasta McMillen @ https://orcid.org/0000-0001-7373-3844 Karl Fraser (® https://orcid.org/0000-0002-1136-4024 Michael Agnew (๑) https://orcid.org/0000-0003-3743-7786 Nicole Roy @ https://orcid.org/0000-0002-6744-9705 